TULIP: Tulisan Ilmiah Pariwisata

E-ISSN: $2720-9873$

Available Online at https://journal.umgo.ac.id/index.php/Tulip/index

Vol. 3, No. 1 Juni 2020

DOI: http://dx.doi.org/10.31314/tulip.3.1.35-41.2020

\title{
MANAJEMEN PSIKOLOGI PELAYANAN DAN HOSPITALITY DALAM PENINGKATAN WISATAWAN MANCANEGARA
}

\section{Sri Sunarti}

Program Studi Pariwisata, Universitas Muhammadiyah Gorontalo, Indonesia

Email; srisunarti@umgo.ac.id

\section{Info Artikel Abstract:}

The purpose of this study is to analyze the form of psychological management

Diterima: 20 in service and hospitality to increase foreign tourists in love island tourism,

Mei 2020 Boalemo district, Gorontalo province. In this study, researchers used descriptive qualitative research methods. The results show that the existence

Disetujui: 02 Juni 2020 of the hospitality industry has a positive impact on the growth of the number of foreign tourists and has an impact on increasing income for the people of Boalemo Regency. And quality services and according to guest needs can have an impact on guest satisfaction levels. The level of guest satisfaction with the quality of service provided is a comprehensive assessment of the superiority of a service related to facilities, services, and good employee responses, can give a good impression or experience for guests, so that it can create a sense of trust and loyalty.

Keywords: Psychology, Hospitality, International Traveler.

\section{Abstrak:}

Tujuan penelitian ini adalah melakukan analisis terhadap bentuk menajemen pisikologi dalam pelayanan dan hospitality untuk meningkatkan wisatawan asing di wisata pulau cinta kabupaten Boalemo provinsi gorontalo. Dalam penelitian ini, peneliti menggunakan metode penelitian kualitataif deskriptif. Hasil penelitian menunjukkan bahwa keberadaan hospitality industry memiliki dampak positif terhadap pertumbuhan jumlah wisatawan asing dan berdampak pada peningkatan pendapatan bagi masyarakat Kabupaten Boalemo. Dan Pelayanan yang berkualitas dan sesuai dengan kebutuhan tamu dapat berdampak pada tingkat kepuasan tamu. Tingkat kepuasan tamu tersebut terhadap kualitas pelayanan yang diberikan merupakan penilaian menyeluruh atas keunggulan suatu jasa terkait fasilitas, pelayanan, dan respon karyawan yang baik, dapat memberikan kesan atau pengalaman yang baik bagi tamu, sehingga bisa memunculkan rasa percaya dan loyal.

Kata Kunci: Psikologi, Hospitality, Wisatawan Mancanegara

\section{PENDAHULUAN}

Electronic marketing yang digunakan untuk Pariwisata merupakan salah satu sektor yang sangat menjanjikan terutama bagi negara yang memiliki keanekaragaman budaya, tradisi dan objek wisata. Bila digarap dengan baik maka semuanya itu dapat menjadi sumber pendapatan dan kemakmuran bagi masyarakat yang berhubungan langsung dengan kegiatan 
pariwisata tersebut maupun yang terkena dampaknya secara tidak langsung.

Untuk memajukan pariwisata diperlukan fasilitas-fasilitas yang dapat menunjangnya yaitu hospitality industry. Keberadaan hospitality industry di suatu daerah menjadi daya tarik yang sangat besar bagi wisatawan mancanegara baik yang tujuannya untuk mencari hiburan maupun untuk tujuan bisnis. Kabupaten boalemo memiliki berbagai macam daya tarik wisata seperti pulau cinta, pantai bolihutuo, pantai langa, pantai asiangi boalemo.

Hospitality bukan hanya soal keramahtamahan seperti dalam arti sempit bahasa (hospitable). Namun hospitality yang merupakan pengetahuan dan seni yang kompleks dalam menjual jasa, yaitu jasa dengan pelayanan yang penuh rasa hormat dan penuh rasa kemanusiaan sesuai kebutuhan jiwa manusia yang ingin dihormati dan dihargai sebagai manusia seutuhnya yang memiliki akal dan budi. Bisnis hospitality bukan hanya tentang menjual kamar-kamar hotel kelas elit, ataupun menjual makananmakanan enak untuk sekedar memenuhi kebutuhan perut. Akan tetapi bisnis hospitality adalah bisnis yang membutuhkan jiwa atau ruh dalam sendisendi operasionalnya. Hospitality adalah mengenai bagaimana menciptakan produk mati menjadi hidup, sehingga langsung dapat menyentuh perasaan pelanggan sebagai manusia yang juga memiliki jiwa (ruh). Dalam hospitality, melayani sepenuh hati merupakan kunci dalam memberikan pelayanan kepada pelanggan, termasuk membantu aktualisasi diri mereka memenuhi jiwa manusia sejati. Pelayanan sepenuh hati tersebut harus mampu diaplikasikan pelaku usaha selaku penyedia jasa yang baik. Dengan kondisi demikian diharapkan pelanggan atau wisatawan akan merasa puas, semakin mencintai produk yang kita tawarkan, bahkan kalau bisa loyal, atau membuat rekomendasi produk kita kepada rekan-rekanya. Selain dimaknai sebagai konsep kata kerja, yaitu "ramah tamah." Hospitality lebih umum juga sering dikenal sebagai sebuah nama atau bentuk usaha jasa pariwisata yang spesifik (sebagai kata benda). Pandangan umum mengatakan bahwa usaha hospitality adalah usaha pariwisata, meliputi bentuk usaha akomodasi (accomodation), usaha makanan dan minuman (food and beverage), resort, usaha atraksi dan rekreasi (atraction and recreation), usaha taman wisata (theme park), cinema, permainan dan judi (game/ casino) dan lain masih banyak lagi. Selain yang disebutkan diatas dapat kita sepakati bahwa setiap bentuk usaha jasa memiliki kewajiban untuk menerapkan hospitality dalam setiap pelayananya, maka setiap usaha jasa yang menuntut adanya kontak langsung antar manusia dapat kita sebut sebagai usaha hospitality

Wisata pulau cinta ini memiliki keindahan pulau ini layak di sandingkan dengan pulau maldives, karena sama-sama menyajikan ekosistem pantai yang lekat dengan nuansa romantis. Ada 15 cottage dengan design unik yang mengelilingi pulau cinta, sangat cocok untuk destinasi wisata dan bulan madu yang tak terlupakan selain kegiatan snorkling,diving,menikmati sunset, beberapa wisata menjadikan tempat ini sebagai lokasi preweding favorit di gorontalo.

Pulo Cinta ini memiliki bentuk yang mirip dengan jantung hati. Di sekitarnya telah dibangun sebuah resort yang juga berbentuk jantung hati. pulau ini memang memiliki daya tarik tersendiri mengingat keindahan yang ada di sekitarnya patut untuk dieksplor lebih luas lagi. Destinasi wisata yang tak kalah indah dan romantisnya dengan objek wisata yang ada di luar negeri.

Pulau romantis ini memiliki pemandangan darat dan laut yang 
menakjubkan. Anda akan disuguhi pemandangan hamparan laut yang bersih dan jernih dengan hembusan angin yang sejuk. Pasir di pulau ini berwarna putih dan lembut di kulit. Selain itu, pemandangan bawah laut tidak boleh Anda lewatkan saat berkunjung ke pulau ini.

Pulau Cinta berada potoameme kecamatan botumoito, kabupaten boalemo Provinsi Gorontalo. Agar bisa sampai di tempat ini pengunjung bisa menggunakan pesawat ke Air Port Jalaluddin dan melanjutkan perjalanan ke Pantai Bolihutuo dan menaiki kapal selama kurang lebih 15 menit agar bisa sampai di pulau ini.

Tak hanya bentuknya yang unik tetapi ada kisah dibalik pulau ini. Dulu ketika ada di masa penjajahan kolonial Belanda, pulau ini memang mejnadi tempat pelarian antara Pangeran Gorontalo dengan putri dari salah seorang pedagang yang berasa dari Belanda. Saat itu terjadi peperangan dan penolakan dari masyarakat setempat. Alhasil cinta dua orang ini tak direstui dan memilih untuk melarikan diri serta mengasingkan diri ke pulau ini.

Bagi para pengunjung yang datang dan ingin menginap di Pulo Cinta ini bisa memilih berbagai macam villa yang ada di sekitarnya. Ada villa dengan 1 kamar tidur yang dibangun dengan luas sekitar 92 meter persegi. Ada juga 10 uni resort di pulau tersebut. Sementara untuk tarifnya sendiri memiliki tarif sekitar Rp. 3.500 .000 per malam di hari biasa. Berbeda di akhir pekan, dikenakan biaya sebesar Rp. 4.500.000 per malamnya. Di hari libur akan dikenakan sebesar Rp. 5.000.000 per malam dimana tarif ini memang untuk 1 villa.

Berbeda untuk pengunjung yang ingin menggunakan 2 kamar tidur dalam 1 villa. Di Pulau Cinta ada 1 unit villa dengan fasilitas 2 kamar. Luasnya sekitar 152 meter persegi dengan tarif sebesar 7 juta per malam di hari biasa. Sementara di akhir pekan tarfinya bisaa sebesar Rp. 9.000.000 per malam. Untuk hari libur, harga bisa menjadi Rp. 10.000.000 per malam dimana villa ini bisa menampung tamu sebanyak 4 orang.

Berikutnya untuk mereka yang menginginkan fasilitas 3 kamar tidur tersedia 1 unit dengan luas sebesar 212 meter persegi. Tarif dari vila ini di hari biasa sebesar Rp. 10.500.000 per malam. Sementara untuk akhir pekan sebesar Rp. 13.500 .000 per malamnya. Di hari libur dikenakan biaya sebesar Rp. 15.000.000 dimana villa ini bisa menampung maksimal 6 orang.

Bagi para wisatawan yang datang ke Pulau Cinta, mereka akan dimanjakan dengan adanya fasilitas yang telah tersedia. Salah satunya adalah antar jemput ke bandara dari bandara Gorontalo hingga ke Desa Patoameme dan menyeberang ke lokasi pulau. Ketika menyeberang, wisatawan bisa menggunakan kapal dengan waktu 2 jam. Fasilitas yang tersedia ini gratis bagi yang menginap selama 3 hari 2 malam. Sementara untuk yang bermalam dengan waktu hanya 2 hari 1 malam dikenakan biaya sebesar Rp. 500.000 .

Ada fasilitas lain yang bisa juga didapatkan oleh para pengunjung seperti sarapan, makan siang dan juga makan malam yang komplit. Ada aneka cemilan dan juga jajanan yang telah disediakan di pulau ini kepada para tamu. Fasilitas seperti teh dan kopi gratis ini ada di setiap kamar. Bagi wisatawan yang ingin melakukan snorkeling juga telah tersedia di pulau romantis ini.

\section{HASIL DAN PEMBAHASAN}

\subsection{Wisatawan}

Wisatawan memiliki beragam motif, minat, ekspektasi, karakteristik sosial, ekonomi, budaya, dan sebagainya (Heher: 2003). Dengan motif dan latar belakang yang berbeda-beda itu mereka menjadi pihak yang 
menciptakan permintaan produk dan jasa wisata. Peran ini sangat menetukan dan sering diposisikan sebagai jantung kegiatan pariwisata itu sendiri.(Heryati, 2019)

Wisatawan adalah orang yang mengadakan perjalanan dari tempat kediamannya tanpa menetap di tempat yang didatanginya atau hanya untuk sementara waktu tinggal di tempat yang didatanginya. Organisasi Wisata Dunia (WTO), menyebut wisatawan sebagai pelancong yang melakukan perjalanan pendek. Menurut organisasi ini, wisatawan adalah orang yang melakukan perjalanan ke sebuah daerah atau negara asing dan menginap minimal 24 jam atau maksimal enam bulan di tempat tersebut (Soekadijo: 1997).

Wisatawan adalah konsumen atau pengguna produk dan layanan. Perubahanperubahan yang terjadi dalam kehidupan mereka berdampak langsung pada kebutuhan wisata, yang dalam hal ini permintaan wisata.(Pradana, 2019)

Ciri-ciri wisatawan adalah :

a. Melakukan suatu perjalanan di luar tempat tinggal, sehubungan dengan berbagai keperluan seperti rekreasi, liburan, kesehatan, pendidikan, tugastugas, pekerjaan, usaha bisnis, kesenian, ilmu pengetahuan, ibadah, olahraga dan pameran.

b. Melakukan perjalanan dan persinggahan di tempat lain untuk sementara waktu tanpa bermaksud untuk memperoleh pengasilan tetap ditempat yang dikunjungi.

\subsection{Manajemen Psikologi Pelayanan Di Wisata Pulau Cinta Kecamatan \\ Botumoito, Kabupaten Boalemo ProvinsiGorontalo}

Pemberian pelayanan yang baik kepada kosumen oleh suatu perusahaan, akan menciptakan kepuasan konsumen. Apabila konsumen merasa puas, mereka akan melakukan pembelian ulang dan merekomendasikan kepada orang lain untuk membeli ditempat yang sama. Oleh sebab itu perusahaan harus mulai memikirkan pentingnya pelayanan pelanggan secara lebih matang melalui kualitas pelayanan, karena semakin disadari kini pelayanan merupakan aspek vital dalam rangka mempertahankan bisnis dan memenangkan persaingan

Psikologi merupakan salah satu bidang ilmu pengetahuan yang penerapannya sangat luas di kehidupan kita sehari-hari. Salah satu penerapan psikologi yang banyak dirasakan adalah dalam bidang pelayanan jasa, salah satunya usaha perhotelan.

Peranan psikologi dalam usaha perhotelan sangatlah besar karena dalam usaha ini yang diperjual belikan adalah jasa antar manusia. Maka, tentu saja dalam hal ini psikologi memiliki andil yang besar.

Menurut Plato, psikologi adalah ilmu pengetahuan yang mempelajari sifat serta hakikat hidup dan jiwa manusia. Sementara itu, ahli psikologi yang lain, Mac Dugall, psikologi adalah ilmu pengetahuan yang mempelajari tingkah laku manusia. Namun, kedua pengertian psikologi tersebut masih beriringan dan memiliki inti pengertian yang sama, yaitu ilmu yang mempelajari hakikat hidup dan jiwa manusia yang di dalamnya juga terdapat perilaku manusia itu sendiri.

Ilmu psikologi merupakan ilmu yang sangat penting karena kita sebagai manusia tidak akan lepas dari bersosialisasi dengan manusia yang lain. Untuk bersosialisasi itulah kita memerlukan ilmu psikologi agar lebih mudah memahami bagaimana perilaku manusia serta menentukan sikap yang tepat untuk meresponnya.

Dalam hal ini pula, psikologi memiliki peran penting dalam usaha pelayanan jasa seperti usaha perhotelan. Pemberian jasa dituntut untuk selalu menjaga kualitas demi 
menjaga kepuasan pelanggan atau konsumen jasa tersebut. Berikut ini adalah pentingnya pemberian kualitas layanan jasa yang baik:

a. Penyediaan pelayanan jasa merupakan tempat berkumpulnya uang.

b. Persaingan yang makin ketat dalam pelayanan jasa, membuat pemberian layanan tersebut membutuhkan 'diferensiasi' yang signifikan untuk pelanggan.

c. Pelanggan semakin memahami tentang kualitas pelayanan, sehingga mereka lebih ingin diperlakukan spesial sebagai tamu.

Melihat pentingnya tingkat kualitas layanan jasa, maka dibutuhkan ilmu psikologi agar bisa lebih memahami keinginan pelanggan dan bagaimana memenuhi keinginan tersebut. Berikut ini akan dibahas mengenai peranan psikologi dalam usaha perhotelan:

1. Menciptakan hubungan sosial yang baik

Ilmu psikologi, seperti psikologi komunikasi, tentu bertujuan untuk bisa menciptakan hubungan sosial yang baik. Maka, peran pertama psikologi dalam usaha perhotelan adalah untuk menciptakan hubungan sosial yang baik sehingga baik karyawan dan tamu hotel merasa nyaman untuk saling berinteraksi.

2. Membantu memahami perilaku konsumen

Tidak bisa dipungkiri bahwa usaha perhotelan juga merupakan usaha bisnis yang memiliki konsumen. Oleh karena itu, kita perlu memahami perilaku konsumen tersebut agar bisa memberi produk dan jasa yang sesuai dengan keinginan mereka. Ilmu psikologi dalam hal ini sangat membantu untuk memahami perilaku konsumen, yaitu dengan memberi pemahaman tentang cara mereka berpikir, bagaimana tingkah laku mereka, persepsi, hingga bagaimana hal-hal di sekitar konsumen dapat mempengaruhi keputusan mereka.

3. Membantu menentukan SOP pelayanan

Memahami ilmu psikologi akan sangat membantu pihak manajemen dalam menyusun SOP pelayanan di hotel. Usaha perhotelan, yang menyediakan pelayanan jasa, tidak hanya menjual persewaan kamar hotel melainkan menjual pengalaman untuk para tamu selama tinggal di hotel tersebut.

Sejak tamu datang di lobi hotel, masuk ke kamar hotel, hingga nanti saat tamu pergi meninggalkan hotel, semuanya harus berlangsung menyenangkan agar para tamu merasa senang dan nyaman tinggal di hotel tersebut. Setiap karyawan di hotel pasti memiliki karakter dan keahlian yang berbeda-beda. Ada karyawan yang memang luwes dalam berinteraksi sosial dan ada pula karyawan yang cenderung kaku ataupun pendiam. Hal ini tentu sangat perlu untuk diperhatikan dalam usaha perhotelan, karena para karyawan ini akan banyak berinteraksi langsung dengan para tamu yang datang.

Indonesia dikenal sebagai negara dengan banyak potensi Sumber Daya Alam, terutama di bidang maritim. Indonesia adalah negara kepulauan terbesar di dunia yang terdiri dari 17.499 pulau dengan garis pantai sepanjang $81.000 \mathrm{~km}$ dan perairannya terdiri dari laut teritorial, perairan kepulauan dan perairan pedalaman yang mencakup 2,7 juta $\mathrm{km}$ atau sebesar 70\% dari wilayah Indonesia. Wilayah laut dan pesisir Indonesia dengan keanekaragaman hayati yang cukup tinggi di hutan mangrove, terumbu karang, padang lamun, rumput laut serta pariwisata bahari dan hasil perikanan telah menjadi pusat 
pertumbuhan baru bagi pembangunan dan peningkatan perekonomian masyarakat.

Pemanfaatan sumber daya alam apabila tidak dilakukan secara tepat maka dapat menjadi tidak terkendali dan mengancam ekosistem dalam menunjang kehidupan manusia dan pembangunan. Oleh karena itu, pemanfaatan sumber daya terutama sumber daya laut dan pesisir hendaknya dapat tegas dalam kegiatan-kegiatan seperti pencemaran hutan mangrove, pembangunan pantai untuk kawasan permukiman atau pariwisata. Karena menurut Beder (1996) dalam keberlanjutan Sumber Daya Alam berupa keberadaan dan pemanfaatannya berhubungan erat dengan ekosistem.

Pulau Cinta, merupakan salah satu tujuan wisata utama di Gorontalo. Pulo Cinta merupakan resort yang berada di tengah pulau kecil di Kabupaten Boalemo, Gorontalo. Sebagai daya tarik utama, Dinas Pariwisata Boalemo terus berupaya untuk mengembangkan potensi dari pulau ini dengan membuat beberapa fasilitas untuk para wisatawan seperti Eco Resort.

Pengelolaan terpadu merupakan suatu pendekatan pengelolaan wilayah pesisir atau suatu upaya yang sudah terprogram dengan melihat potensi sumber daya, melibatkan beberapa ekosistem, serta upaya pemanfaatan secara terpadu untuk mengoptimalkan kepentingan untuk memelihara lingkungan, keterlibatan masyarakat, dan peningkatan ekonomi demi mencapai pembangunan wilayah pesisir yang berkelanjutan (Subagiyo, 2017).

\subsection{Hospitality Dalam Peningkatan Wisatawan Mancanegara Di Wasata Pulau Cinta Kecamatan Botumoito, Kabupaten Boalemo, Provinsi Gorontalo.}

Sektor pariwisata tidak dapat dipisahkan keberadaannya dari hospitality industry. Dimana peningkatan jumlah hospitality industry memiliki dampak yang besar bagi pariwisata itu sendiri serta berdampak terhadap meningkatnya jumlah sektor pariwisata berupa penambahan jumlah restoran, rumah makan dan penyediaan fasilitas MICE yang berdampak juga pada peningkatan jumlah wisatawan asing

Wisatawan mancanegara yang berkunjung ke daya tarik wisata pulau cinta di dominasi oleh wisatawan berkewarganegaraan Australia dan di susul wisatawan mancanegara yang berasal dari beberapa negara di bagian Eropa, selanjutnya wisatawan yang berasal dari beberapa Negara Bagian Amerika, dan juga wisatawan yang berasal dari beberapa negara Asia. Bukan tanpa alasan, daya tarik wisata pulau cinta didominasi oleh wisatawan Australia dan juga ada beberapa Wisatawan yang bersal dari negara-negara bagian Eropa, karena pulau cinta memiliki potensi yang jarang dimiliki oleh daya tarik wisata lainnya, yaitu pemandangan darat dan laut yang menakjubkan, anda akan di suguhi pemandangan hamparan laut yang bersih dan jernih dengan hembusan angin yang sejuk.

Wisatawan mancanegara yang berkunjung ke daya tarik wisata pulau cinta kecamatan botumoito,kabupaten boalemo,provinsi gorontalo memiliki sikap dan karakteristik yang berbeda-beda sehingga para pengelola wisata pulau cinta harus meberikan pelayan yang baik agar wisatawan yang datang berkunjung ke daya tarik wisata pulau cinta akan merasa puas dengan pelayanan yang di berikan.

\section{KESIMPULAN}

Dari analisis dapat disimpulkan bahwa keberadaan hospitality industry memiliki dampak positif terhadap pertumbuhan jumlah wisatawan asing dan 
berdampak pada peningkatan pendapatan bagi masyarakat Kabupaten Boalemo. Pemerintah Kabuapten Boalemo dapat berperan aktif dalam memajukan pariwisata dengan cara mempermudah perizinan pendirian hotel, restoran dan fasilitas MICE.

Pelayanan yang berkualitas dan sesuai dengan kebutuhan tamu dapat berdampak pada tingkat kepuasan tamu. Tingkat kepuasan tamu tersebut terhadap kualitas pelayanan yang diberikan merupakan penilaian menyeluruh atas keunggulan suatu jasa terkait fasilitas, pelayanan, dan respon karyawan yang baik, dapat memberikan kesan atau pengalaman yang baik bagi tamu, sehingga bisa memunculkan rasa percaya dan loyal.

\section{REFERENSI}

Akmaliyah, M. (2013), Journal of Chemical Information and Modeling, 53(9), pp. 1689-1699.

F, K. Ge. (1967) Angewandte Chemie International Edition, 6(11), 951-952., pp. 4-19.

Hermawan, H., Brahmanto, E. and Hamzah, F. (2018) 'Pengantar Manajemen Hospitality'. doi:
Heryati, Y. (2019) 'Potensi Pengembangan Obyek Wisata Pantai Tapandullu Di Kabupaten Mamuju', GROWTH Jurnal Ilmiah Ekonomi ..., 1(1), pp. 56-74. Available at: https://stiemmamuju.ejournal.id/GJIEP/article/view/10.

laita, natania, Tyasrani, S. F. and Pariwisata, R. O. (2018) 'Upaya Warung Taichan Dalam Menciptakan Kepuasan Pelanggan'. doi: 10.31227/osf.io/cemzu.

Pradana, G. Y. K. (2019) 'Sosiologi Pariwisata', STPBI Press, 1(1), pp. 1-88.

Sakerebau, J. (2018) 'Memahami Peran Psikologi Pendidikan Bagi Pembelajaran', BIA': Jurnal Teologi dan Pendidikan Kristen Kontekstual, 1(1), pp. 96-111. doi: 10.34307/b.v1i1.22. 10.31227/osf.io/7cymx. 